\title{
Pichia caribaea, a New Species of Yeast Occurring in Necrotic Tissue of Cacti in the Caribbean Area
}

\author{
HERMAN J. PHAFF, ${ }^{1 *}$ WILLIAM T. STARMER,${ }^{2}$ M. A. LACHANCE, ${ }^{3}$ VIRGINIA ABERDEEN, ${ }^{2}$ AND \\ JOANNE TREDICK-KLINE ${ }^{1}$ \\ Department of Food Science \& Technology, University of California, Davis, California 95616 ${ }^{1}$; Department of \\ Biology, Syracuse University, Syracuse, New York $13210^{2}$; and Department of Plant Sciences, University of \\ Western Ontario, London, Ontario, Canada $N 6 A 5 B 7^{3}$
}

\begin{abstract}
We describe Pichia caribaea, a new species of yeast which is closely related to $P$. amethionina. $P$. caribaea, of which 92 strains were isolated, is heterothallic and occurs in nature in both the haploid state and the diploid state. It produces asci with four hat-shaped spores, which are gradually released upon maturity. $P$. caribaea occurs in rotting tissue of cereoid and opuntia cacti on various islands in the greater Caribbean area and on coastal land masses surrounding it. It resembles $P$. amethionina var. pachycereana in its assimilation pattern of carbon compounds but differs in its ability to ferment glucose strongly. The DNAs of $P$. caribaea and the two described varieties of $P$. amethionina show about $40 \%$ complementarity. The type strain of $P$. caribaea is strain UCD-FST 81-62 (= ATTC 76713 = CBS 7692).
\end{abstract}

In 1978, Starmer et al. (15) described Pichia amethionina, a naturally occurring auxotroph that has an absolute requirement for organic forms of sulfur, such as the sulfur-containing amino acids L-methionine and L-cysteine. This nonfermentative species is represented by two varieties, $P$. amethionina var. amethionina and $P$. amethionina var. pachycereana. The former is commonly recovered from rot pockets in cacti of the subtribe Stenocereinae, whereas the latter has its principal habitat in members of the subtribe Pachycereinae (2, 15). All isolates of these two varieties came from decaying columnar and Opuntia cacti in the North American Sonoran desert, including the Baja California peninsula. The DNA relatedness between the two varieties was determined by Holzschu and Phaff (3), who reported a mean DNA-DNA complementarity value of $64.9 \%$ $\pm 3.2 \%$ on the basis of 16 pairwise comparisons, including reverse DNA reassociations. Nearly all strains of $P$. amethionina var. amethionina lack the ability to utilize D-mannitol for growth and are resistant to triterpene glycosides or digitonin at $25^{\circ} \mathrm{C}$, while $P$. amethionina var. pachycereana is $\mathrm{D}$-mannitol positive and is inhibited by these compounds (12).

During two expeditions in 1982 and 1983 to collect yeasts from cactus necroses on various islands in the Caribbean Sea and the Bahamas, we discovered another yeast with an absolute requirement for sulfur-containing amino acids that was similar to $P$. amethionina var. pachycereana, except that glucose was vigorously fermented. Additional strains with these properties had been isolated by J. W. Fell and later by M. A. Lachance in the Exuma chain in the Bahamas, by Starmer and Phaff (14) on the Gulf of Mexico coast of Texas, and more recently by Starmer et al. (10) in Florida. In the publications cited, these isolates were referred to as $P$. amethionina var. " $f$ " or "fermentans." As a formal description with a Latin diagnosis was not provided, this name constitutes a nomen nudum.

To substantiate the basis for a valid description of this group of isolates, we carried out mating tests and DNADNA hybridizations between typical strains of the fermenting isolates and the two varieties of $P$. amethionina. Mating

\footnotetext{
* Corresponding author.
}

between the fermenting isolates and either of the two varieties of $P$. amethionina was limited. The genome comparisons revealed that both varieties exhibited approximately $40 \%$ DNA complementarity with several isolates of the glucosefermenting strains. On this basis, we conclude that these strains comprise a separate species in the genus Pichia, for which we propose the name $P$. caribaea sp. nov., after the geographic area where most of the strains were found.

\section{MATERIALS AND METHODS}

Samples of necrotic cactus tissue yielding $P$. caribaea came from the host plants and locations recorded in Table 1. The samples from Caribbean islands and the Bahamas were collected in May 1982 during cruise CF-8205, in November 1983 during cruise CF-8314 of the research vessel Cape Florida, and in June 1990 during cruise CA-9008 of the research vessel Calanus in that region. The techniques used for yeast isolation and purification have been described previously (14). The strains analyzed for nuclear DNA base composition and those used in the DNA-DNA hybridization studies are listed in Table 2.

The usual phenotypic characterization of the isolates was carried out by methods currently used in yeast taxonomy (18), but additional carbon compounds were used in assimilation tests. These included glucosamine, $N$-acetylglucosamine, methanol, 2-propanol, acetone, and ethyl acetate; we obtained the best differential results by adding the last three compounds tested to $1 \%$ ( $\mathrm{vol} / \mathrm{vol}$ ) (based on medium volume) to the inverted cover of a glass petri dish after inoculation with the test cultures by multipoint inoculation, sealing the dishes with Parafilm M (American Can Co., Greenwich, Conn.), and incubating the dish upside down.

Sensitivity to triterpene glycoside or digitonin was tested at $25^{\circ} \mathrm{C}$ in YM (Difco) agar plates as described by Starmer et al. (12). Triterpene glycosides were tested in a concentration of $1 \%$ dried, powdered Stenocereus gummosus (agria) tissue (a columnar cactus species with a high content of these glycosides) or in a concentration of $8 \mathrm{mg}$ of digitonin per liter (12).

Killer activity was tested against Candida glabrata NRRL Y-55 (11), a strain known for its broad sensitivity to known killer toxins. 
TABLE 1. Geographic and host plant distributions of $P$. caribaea

\begin{tabular}{|c|c|c|}
\hline Locality & Host tissue $^{a}$ & $\begin{array}{c}\text { No. of } P . \\
\text { caribaea } \\
\text { strains isolated }\end{array}$ \\
\hline Quintana Beach, Tex. & Opuntia lindheimeri & 3 \\
\hline Galveston Beach, Tex. & Opuntia lindheimeri & 1 \\
\hline Canaveral National Seashores, Fla. & Opuntia stricta & 6 \\
\hline Canaveral National Seashores, Fla. & Opuntia stricta fruit & 1 \\
\hline Kennedy Space Center, Fla. & Opuntia stricta & 5 \\
\hline Kennedy Space Center, Fla. & Opuntia stricta fruit & 2 \\
\hline Flamingo, Fla. & Opuntia stricta & 4 \\
\hline Tecuacán Pueblo, Mexico & Escontria chiotilla & 1 \\
\hline Tuxtla Gutierrez, Chiapas, Mexico & Nopalea sp. & 1 \\
\hline Airport, Montserrat & Cephalocereus royenii & 5 \\
\hline Spanish Point, Montserrat & Opuntia stricta & 2 \\
\hline Prickly Pear Island, B.V.I. ${ }^{b}$ & Cephalocereus royenii & 5 \\
\hline Prickly Pear Island, B.V.I. & Melocactus intortus & 1 \\
\hline Beef Island, Virgin Gorda, B.V.I. & Cephalocereus royenii & 1 \\
\hline Exuma chain, Bahamas & Opuntia stricta & 19 \\
\hline Conception Island, Bahamas & Opuntia stricta & 1 \\
\hline Conception Island, Bahamas & Opuntia stricta fruit & 1 \\
\hline Matthew Town, Great Inagua, Bahamas & Cephalocereus royenii & 1 \\
\hline Matthew Town, Great Inagua, Bahamas & Opuntia stricta & 1 \\
\hline Matthew Town, Great Inagua, Bahamas & Opuntia stricta fruit & 3 \\
\hline Navassa Island, Caribbean, United States & Opuntia stricta & 8 \\
\hline Navassa Island, Caribbean, United States & Drosophila straubae & 2 \\
\hline Guantanamo Bay, Cuba & Cephalocereus robinii & 1 \\
\hline Discovery Bay, Jamaica & Opuntia stricta & 1 \\
\hline Sandy Bay, Jamaica & Opuntia stricta & 1 \\
\hline Sandy Bay, Jamaica & Opuntia stricta fruit & 1 \\
\hline Cayman Brac, Cayman Islands & Cephalocereus royenii & 4 \\
\hline Cayman Brac, Cayman Islands & Opuntia stricta & 2 \\
\hline Little Cayman, Cayman Islands & Cephalocereus royenii & 2 \\
\hline Little Cayman, Cayman Islands & Opuntia stricta fruit & 1 \\
\hline El Anis, Venezuela & Cereus repandus & 1 \\
\hline Oricao, Venezuela & Cephalocereus langinosus & 1 \\
\hline Piritu, Venezuela & Cereus repandus & 2 \\
\hline Prudencio, Venezuela & Stenocereus griseus & 1 \\
\hline
\end{tabular}

${ }^{a}$ Tissue is the stem of columnar cacti or cladode of Opuntia spp. unless fruit is indicated.

${ }^{b}$ B.V.I., British Virgin Islands.

TABLE 2. Reannealing between labeled DNA from $P$. caribaea UCD-FST $81-62^{\mathrm{T}}$ and DNAs from seven yeast strains and calf thymus control DNA ${ }^{a}$

\begin{tabular}{lcc}
\hline \multicolumn{1}{c}{ Organism or tissue } & Mol\% G+C & $\begin{array}{c}\text { Relative \% binding } \\
\text { with } P . \text { caribaea } \\
81-62^{\mathrm{Tb}}\end{array}$ \\
\hline P. caribaea strains & & \\
UCD-FST $81-62^{\mathrm{T}}$ & 34.4 & 100.0 \\
UCD-FST $81-38$ & 34.4 & 94.1 \\
UCD-FST $81-35$ & 34.0 & 94.4 \\
$\quad$ UCD-FST $81-27$ & 34.0 & 93.0 \\
P. amethionina var. amethionina & 33.1 & 40.2 \\
$\quad$ UCD-FST 76-401B & \\
P. amethionina var. & 33.0 & 37.4 \\
pachycereana UCD-FST & & \\
76-384A & \\
P. cactophila UCD-FST & & 2.3 \\
76-243A & \\
Calf thymus DNA & 36.3 & 0.0 \\
\hline
\end{tabular}

${ }^{a}$ All four $P$. caribaea strains used came from islands in the Exuma chain of the Bahamas.

$b$ 125 I-labeled DNA $(0.2 \mu \mathrm{g})$ and unlabeled DNA $(200 \mu \mathrm{g})$ were incubated at $61.7^{\circ} \mathrm{C}$ for $25 \mathrm{~h}$ in $0.5 \mathrm{ml}$ of $280 \mathrm{mM}$ phosphate buffer, $\mathrm{pH} 6.8$. The values are averages of three determinations and are corrected for zero-time binding and for self-renaturation $(8)$.
DNA extraction and purification were carried out by the methods described by Price et al. (8), except that purified DNA was concentrated by electrophoresis in a concentrator (ISCO, Lincoln, Nebr.), and the reference DNA was labeled with ${ }^{125} \mathrm{I}$ as described by Holzschu et al. (5). The $\mathrm{G}+\mathrm{C}$ contents of the nuclear DNAs were calculated from buoyant density values in cesium chloride gradients established in a Spinco E analytical ultracentrifuge equipped with photographic optics $(9,17)$ and were based on three separate determinations. DNA from Micrococcus luteus 2039 (International Collection of Phytopathogenic Bacteria, Department of Bacteriology, University of California, Davis), with a buoyant density of $1.7309 \mathrm{~g} / \mathrm{ml}$, was used as a reference. The buoyant density of the $M$. luteus DNA was derived from comparison with plasmid-free Escherichia coli K-12 DNA, the buoyant density of which was taken to be $1.700 \mathrm{~g} / \mathrm{ml}$. Denaturation of DNA, incubation for renaturation, analysis of the renaturation kinetics and reannealing reactions, and quantitation of single- and double-stranded DNAs were carried out by using the methods of Price et al. (8). Samples were counted with a TM Analytic 1290 gamma ray counter (84\% efficiency).

Single ascospores were isolated from mature asci with a micromanipulator (1). 


\section{RESULTS}

Single-spore clones of $P$. caribaea showed limited ability to mate with haploid clones of the opposite mating type of $P$. amethionina var. amethionina or $P$. amethionina var. pachycereana. In all combinations (best with $P$. amethionina var. amethionina), zygotes were produced after 2 to 5 days on YM agar, and in some combinations, aberrant asci with three or four malformed spores were observed. This is evidence for reproductive isolation of closely related species. Except for glucose fermentation, the physiological and morphological properties of the isolates listed in Table 1 were very similar to those of $P$. amethionina var. pachycereana (15) and the nuclear DNA base composition of selected strains (Table 2) was slightly higher by approximately 1 mol\% $\mathrm{G}+\mathrm{C}$. These similarities induced us to compare their nuclear genomes by DNA-DNA hybridization. The results (Table 2) of this experiment indicate that $P$. caribaea shows about $40 \%$ DNA relatedness to both varieties of $P$. amethionina. $P$. cactophila was used as a negative control. This level of DNA complementarity shows significant evolutionary relatedness between the species and substantiates the other observations that indicate that the taxa represent distinct species. We therefore propose to describe $P$. caribaea as a new species of the genus Pichia.

Latin diagnosis of Pichia caribaea sp. nov. In YM (Difco) liquido post dies 3 ad $30^{\circ} \mathrm{C}$, cellulae vegetativae ovoideae, pyriformes, clavatae vel elongatae, 2-4 × 4-9 $\mu \mathrm{m}$, interdum longitudo 12-14 $\mu \mathrm{m}$, singulae, binae, in catenis brevis, aut in fasciculae ad instar stellae; sedimentum; pellicula nulla aut tenuis. Cultura in agaro malti post dies 21 ad $25^{\circ} \mathrm{C}$ canacremea, butyrosa vel mollis, umbonata, glabra cum lineis radiatis, semi-nitida, margine glabro vel undulato.

In agaro farinae Zea mays post dies 10, pseudomycelium nullum. Species heterothallica, diploidea aut haploidea. Asci habentes 4 sporos pileiformae; asci rumpunter post dies 5-10.

Fermentatio glucosi. Glucosum, ethanolum, glycerolum, D-mannitolum, acidum lacticum, acidum succinicum, acidum gluconatum, ethylacetas assimilantur at non galactosum, L-sorbosum, maltosum, saccharosum, cellobiosum, trehalosum, lactosum, melibiosum, raffinosum, melezitosum, inulinum, amylum solubile, D-xylosum, L-arabinosum, D-arabinosum, D-ribosum, L-rhamnosum, $i$-erythritolum, ribitolum, galactitolum, D-glucitolum, methyl- $\alpha$-D-glucosidum, salicinum, 2-ketogluconatum, 5-ketogluconatum, acidum citricum, meso-inositolum, D-glucosaminum, $N$-acetylglucosaminum, methanolum, 2-propanolum, acetonum, nec hexadecanum. Kalium nitricum, natrium nitrosum non assimilantur. Ethylaminum, L-lysinum, et cadaverinum assimilantur tarde. Ad crescentiam L-methioninum et vitaminae additae necessariae sunt. Crescere potest in $39^{\circ} \mathrm{C}$, interdum in $41^{\circ} \mathrm{C}$, exigue.

$\mathrm{G}+\mathrm{C}$ acidi deoxyribonucleati $34.0-34.4 \mathrm{~mol} \%$ (4 stirpes). Habitatio in cacti tribus Opuntieae et subtribus Pachycereinae.

Typus: stirps UCD-FST 81-62 ex tabidosus sacculis cacti Opuntia stricta isolata est. In collectione zymotica Centraalbureau voor Schimmelcultures, Delphi Batavorum sub no. 7692 deposita est.

Description of Pichia caribaea sp. nov. Pichia caribaea (ca.rib'ae.a. L. fem. adj., of the Caribbean, referring to the area of its common occurrence). In YM liquid medium after 3 days at $30^{\circ} \mathrm{C}$, the cells are ovoid, pear-shaped, clavate, or short-cylindrical, 2 to 4 by 4 to $9 \mu \mathrm{m}$, sometimes elongate at 12 to $14 \mu \mathrm{m}$ long, single, in pairs, short chains, or asteroidlike configurations, as illustrated in reference 15 for $P$. amethionina; a sediment and a thin ring develop, a pellicle is lacking or very thin, smooth, and creeping. Streak culture on malt agar after 3 weeks at $25^{\circ} \mathrm{C}$ is cream colored to greyish, butyrous to soft, umbonate, smooth with slight lateral striations, and semiglossy, with an entire-to-lobulate periphery.

In Dalmau plate cultures on cornmeal agar after 10 days, pseudomycelium is lacking; occasionally, a few tufts of rudimentary chains of cells may be present.

The cells are haploid or diploid in natural populations. The type strain is diploid and heterothallic, producing three to four small hat-shaped spores per ascus; at maturity, asci gradually release the spores. Two spores are $h^{+}$, and two are $\mathrm{h}^{-}$. After mixing of the haploid clones, strong agglutination is noted, zygotes are formed, and the diplophase is reestablished. Sporulation is best on McClary's acetate agar after 3 to 5 days. Freshly isolated diploid strains also sporulate on YM agar or on dilute malt extract.

Glucose is fermented; a full tube of gas is produced after 3 to 5 days at $30^{\circ} \mathrm{C}$. Assimilation of carbon compounds: positive for glucose, ethanol, glycerol, D-mannitol, lactic acid, succinic acid, gluconic acid, and ethyl acetate. Negative for galactose, L-sorbose, maltose, sucrose, cellobiose, trehalose, lactose, melibiose, raffinose, melezitose, inulin, soluble starch, D-xylose, L-arabinose, D-arabinose, D-ribose, L-rhamnose, $i$-erythritol, ribitol, galactitol, D-glucitol, $\alpha$-methyl-D-glycoside, salicin, 2-ketogluconate, 5-ketogluconate, citric acid, meso-inositol, D-glucosamine, $N$-acetylglucosamine, methanol, 2-propanol, acetone, and hexadecane.

$\mathrm{KNO}_{3}$ and $\mathrm{NaNO}_{2}$ are not utilized as sole sources of nitrogen; ethyl amine, L-lysine, and cadaverine are slowly utilized.

L-Methionine or L-cysteine and $\mathrm{B}$ vitamins are required in synthetic media. Growth occurs at $39^{\circ} \mathrm{C}$ and in some strains weakly at $41^{\circ} \mathrm{C} . \mathrm{G}+\mathrm{C}$ content of the nuclear DNA is 34.0 to $34.4 \mathrm{~mol} \%$ (four strains, buoyant density).

Killer activity is lacking or extremely weak in all strains on Candida glabrata NRRL Y-55 as the sensitive strain.

Sensitivity to triterpene glycosides or digitonin is variable. The type strain is sensitive. Growth in the presence of $1 \mu \mathrm{g}$ of cycloheximide per ml: negative.

Growth on $\mathrm{YM}$ agar-5\% $\mathrm{NaCl}$ is weak to good, that on $7.5 \% \mathrm{NaCl}$ is weak or negative, and that on $10 \% \mathrm{NaCl}$ is negative.

Growth on $50 \%$ glucose is negative.

Casein hydrolysis is negative.

Gelatin hydrolysis is negative or latent and weak. Type strain is negative.

Lipolytic activity is negative.

Urease activity is negative.

Habitat is in necrotic tissue of cacti in the tribe Opuntieae and in columnar cacti of the subtribe Pachycereinae.

The type strain is UCD-FST 81-62, isolated from Opuntia stricta growing on one of the cays of the Exuma chain in the Bahamas. It has been deposited in the American Type Culture Collection under no. 76713 and in the Centraalbureau voor Schimmelcultures collection, Delft, The Netherlands, under no. 7692 .

\section{DISCUSSION}

$P$. caribaea and $P$. amethionina are distinct but closely related species, as evidenced by their limited ability to mate and occasionally to form ascospores. Mating between haploid forms of closely related species is not uncommon, as reported by Kurtzman and co-workers $(6,7)$. When tested, spores in such asci were normally found to be nonviable (6). 
DNA hybridization (Table 2) shows that $P$. caribaea exhibits approximately $40 \%$ base sequence complementarity with both varieties of $P$. amethionina. Although significant, this level of DNA relatedness is well below that usually found in conspecifics. Similar cases of significant degrees of DNA relatedness among cactophilic yeast species have been reported for $P$. cactophila and $P$. pseudocactophila (ca. $35 \%$ ) (4) and between $P$. antillensis and $P$. opuntiae (ca. $50 \%)(16)$.

Phenotypically, $P$. caribaea is most similar to $P$. amethionina var. pachycereana in its assimilation pattern of carbon compounds, but it differs in its ability to ferment glucose vigorously. This ability by itself, however, does not guarantee that one is dealing with separate species. For example, Price et al. (8) showed that Debaryomyces formicarius and $D$. vanrijiae exhibit $96 \%$ DNA complementarity, but the former ferments glucose (albeit slowly), while the latter does not.

Geographically, $P$. caribaea appears to be restricted to decaying tissue of Opuntia spp. and columnar cacti of the subtribe Pachycereinae on islands in the broad area composed of the Bahamas, the Caribbean Sea, the Gulf of Mexico, and coastal landmasses that border these areas (Table 1). Although widespread in this area, it has only rarely been isolated from members of the subtribe Stenocereinae. On certain Caribbean islands, where it was found in $9.5 \%$ of the samples tested, it accounted for $5.3 \%$ of the regional yeast community (13). In contrast, $P$. amethionina var. amethionina and $P$. amethionina var. pachycereana have not been found in the Caribbean area or in northern Venezuela but have overlapping distributions in the Sonoran desert and the southwestern United States, including the Baja California peninsula (15).

The principal host plants of $P$. caribaea are members of the subtribe Pachycereinae and Opuntia species which lack triterpene glycosides in their tissue $(2,12)$. On this basis, one would expect $P$. caribaea strains to be sensitive to these compounds (12), which are highly toxic to yeast strains not adapted to them, as are most strains of $P$. amethionina var. pachycereana (3). This was not the case, however, as we determined that approximately $40 \%$ of the strains listed in Table 1 were resistant. Even among the sensitive strains, of which most were totally inhibited from growing, some produced spotty resistant colonies that developed latently on plates containing triterpene glycosides, possibly owing to mutation. Resistance to triterpene glycosides is controlled by a single temperature-sensitive nuclear gene (12). To account for the occurrence of fully resistant strains from cacti that do not contain these inhibitory compounds, one could postulate that resistance to triterpene glycosides is the result of gene flow between strains of $P$. amethionina var. amethionina and $P$. caribaea by way of aneuploidy and nondisjunctive recombination, even without the sporulation process. However, our finding that these two species are not sympatric argues against this hypothesis. The few isolates of $P$. caribaea that did originate from cacti of the subtribe Stenocereinae were from the periphery of the geographic distribution, i.e., Venezuela and Mexico. Gene flow from resistant strains in these areas could also account for resistance in the centrally located strains. Because resistance to triterpene glycosides is most likely due to conformational changes in the cell membrane, it is also possible that the resistance is due to other membrane-associated adaptations of $P$. caribaea.

\section{ACKNOWLEDGMENTS}

This work was supported by grants BSR8701753 (to W.T.S.) and DEB-81-08898 (to H.J.P.) from the National Science Foundation and an operating grant from the Natural Science and Engineering Council of Canada (to M.A.L.).

We thank J. W. Fell for supplying strains collected on the Exuma chain in the Bahamas and Francesc Peris and Antonio Fontdevila for access to their collection records on yeasts from Venezuela.

\section{REFERENCES}

1. Fowell, R. R. 1969. Sporulation and hybridization of yeasts, p. 303-383. In A. H. Rose and J. S. Harrison (ed.), The yeasts, vol. 1. Academic Press, Inc., New York.

2. Gibson, A. C., and K. E. Horak. 1978. Systematic anatomy and phylogeny of Mexican columnar cacti. Ann. Mo. Bot. Gard. 65:999-1057.

3. Holzschu, D. L., and H. J. Phaff. 1982. Taxonomy and evolution of some ascomycetous cactophilic yeasts, p. 127-141. In J. S. F. Barker and W. T. Starmer (ed.), Ecological genetics and evolution. The cactus-yeast-Drosophila model system. Academic Press Australia, Sydney, Australia.

4. Holzschu, D. L., H. J. Phaff, J. Tredick, and D. Hedgecock. 1983. Pichia pseudocactophila, a new species of yeast occurring in necrotic tissue of columnar cacti in the North American Sonoran desert. Can. J. Microbiol. 29:1314-1322.

5. Holzschu, D. L., H. L. Presley, M. Miranda, and H. J. Phaff. 1979. Identification of Candida lusitaniae as an opportunistic yeast in humans. J. Clin. Microbiol. 10:202-205.

6. Kurtzman, C. P. 1984. DNA base sequence complementarity and the definition of fungal taxa. Microbiol. Sci. 1:44-48.

7. Kurtzman, C. P., M. J. Smiley, C. J. Johnson, L. J. Wickerham, and G. B. Fuson. 1980. Two new and closely related heterothallic species, Pichia amylophila and Pichia mississippiensis: characterization by hybridization and deoxyribonucleic acid reassociation. Int. J. Syst. Bacteriol. 30:208-216.

8. Price, C. W., G. B. Fuson, and H. J. Phaff. 1978. Genome comparison in yeast systematics: delimitation of species within the genera Schwanniomyces, Saccharomyces, Debaryomyces, and Pichia. Microbiol. Rev. 42:161-193.

9. Schildkraut, C. L., J. Marmur, and P. Doty. 1962. Determination of the base composition of deoxyribonucleic acid from its buoyant density in CsCl. J. Mol. Biol. 4:430-433.

10. Starmer, W. T., V. Aberdeen, and M. A. Lachance. 1988. The yeast community associated with decaying Opuntia stricta (Haworth) in Florida with regard to the moth, Cactoblastis cactorum (Berg). Fla. Sci. Biol. Sci. 51:7-11.

11. Starmer, W. T., P. F. Ganter, V. Aberdeen, M. A. Lachance, and H. J. Phaff. 1987. The ecological role of killer yeasts in natural communities of yeasts. Can. J. Microbiol. 33:783-796.

12. Starmer, W. T., H. W. Kircher, and H. J. Phaff. 1980. Evolution and speciation of host plant specific yeasts. Evolution 34:137146.

13. Starmer, W. T., M. A. Lachance, H. J. Phaff, and W. B. Heed. 1990. The biogeography of yeasts associated with decaying cactus tissue in North America, the Caribbean, and northern Venezuela. Evol. Biol. 24:253-296.

14. Starmer, W. T., and H. J. Phaff. 1983. Analysis of the community structure of yeasts associated with the decaying stems of cactus. II. Opuntia species. Microb. Ecol. 9:247-259.

15. Starmer, W. T., H. J. Phaff, M. Miranda, and M. W. Miller. 1978. Pichia amethionina, a new heterothallic yeast associated with decaying stems of cereoid cacti. Int. J. Syst. Bacteriol. 28:433-441.

16. Starmer, W. T., H. J. Phaff, J. Tredick, M. Miranda, and V. Aberdeen. 1984. Pichia antillensis, a new species of yeast associated with necrotic stems of cactus in the Lesser Antilles. Int. J. Syst. Bacteriol. 34:350-354.

17. Szybalski, W. 1969. Use of cesium sulfate for equilibrium density gradient centrifugation. Methods Enzymol. 12:330-360.

18. van der Walt, J. P., and D. Yarrow. 1984. Methods for the isolation, maintenance, classification and identification of yeasts, p. 45-104. In N. J. W. Kreger-van Rij (ed.), The yeasts-a taxonomic study. Elsevier Publishing Co., Amsterdam. 